\title{
Novel Resorcinol Derivatives from Lasiodiplodia theobromae
}

\author{
Qing Yang, Maki Asai and Teruhiko Yoshihara*
}

Division of Applied Bioscience, Graduate School of Agriculture, Hokkaido University, Sapporo, 060-8589, Japan. Fax: +81-11-706-2505.

E-mail: yosihara@chem.agr.hokudai.ac.jp

* Author for correspondence and reprint request

Z. Naturforsch. 55c, 546-551 (2000); received February 10/March 14, 2000

Lasiodiplodia theobromae, Potato Micro-Tuber Inducing Substance, Resorcinol Derivatives

Two novel resorcinol derivatives were isolated from the mycelium of Lasiodiplodia theobromae IFO 31059 as potato micro-tuber inducing compounds. Their structures were established by spectroscopic methods as ethyl ( $\left.6^{\prime} R\right)$-2,4-dihydroxy-6-( $6^{\prime}$-hydroxyheptyl)benzoate (8) and isobutyl (6' $R$ )-2,4-dihydroxy-6-(6'-hydroxyheptyl)benzoate (9). The absolute stereochemistry of the asymmetric center of (8) was determined by an advanced Mosher method.

\section{Introduction}

Lasiodiplodia theobromae is a fungus whose culture filtrate inhibits the growth of higher plants, and produces various organic metabolites (Aldridge et al., 1971). In our ongoing screening program for potato micro-tuber inducing substances from microorganisms, we previously isolated jasmonic acid (1), theobroxide (2) (Nakamori et al., 1994), 5-oxolasiodiplodin (3), 5-hydroxylasiodiplodins $(\mathbf{4 a})$ and $(\mathbf{4 b}),(3 R, 4 S)$-4-hydroxylasiodiplodin $(5),(3 R, 6 R)$-6-hydroxy-de- $O$-methyllasiodiplodin (6) and $(3 R, 5 R)$-5-hydroxy-de- $O$ methyllasiodiplodin (7) (Matsuura et al., 1998; Yang et al., 2000) from this fungus (Fig. 1). As a result of continuing research on this fungus, bioassay-directed fractionation of the extract has now led to the isolation and characterization of two novel resorcinol derivatives: ethyl $\left(6^{\prime} R\right)$-2,4-dihydroxy-6-(6'-hydroxyheptyl)benzoate $(\mathbf{8})$ and isobutyl (6'R)-2,4-dihydroxy-6-(6'-hydroxyheptyl)benzoate (9) as biologically active compounds inducing potato micro-tuber formation. This appears to be the first instance in which $\mathbf{8}$ and $\mathbf{9}$ have been isolated from a natural source and demonstrated to have such activity.

\section{Materials and Methods}

\section{Instrumental analyses}

Spectra were obtained with the following instruments: IR, Hitachi 285 spectrometer; optical rotations, JASCO DIP-4 polarimeter; NMR, Bruker
AM-500 FT-NMR spectrometer and JEOL JNMEX 270 FT-NMR system; FD- and EI-MS, JEOL JMS01SG-2 and JMS-DX-300 mass spectrometers, respectively.

\section{Chemicals}

(-)-MTPACl and (+)-MTPACl were purchased from Wako company, Tokyo, Japan.

\section{Bioassay}

Potato micro-tuber inducing activity was assayed using cultures of single-node segments of potato stems in vitro, as reported previously (Koda and Okazawa, 1988). In brief, single-node segments prepared from etiolated potato shoots ( $\mathrm{So}$ lanum tuberosum L. cv Irish Cobber), were sterilized in a $1 \%$ solution of sodium hypochlorite for $1 \mathrm{~h}$. Then three segments were transferred to a $100 \mathrm{ml}$ flask that contained $10 \mathrm{ml}$ of medium (usually white's medium with $2 \%$ sucrose) supplement with the compound to be tested. The medium was adjusted to pH 5.6 and solidified with $0.6 \%$ Bactoagar before being autoclaved. Five replicates of each culture were maintained at $25^{\circ} \mathrm{C}$ in the dark for 3 weeks, and the ratio of tuberization was calculated as the number of tuberized laterals divided by the total number of laterals that had emerged. Jasmonic acid $\left(10^{-5} \mathrm{M}\right)$ was used as the positive standard, and a medium without the extract (or the test compound) was used as the negative control. 
<smiles>CCC=CCC1C(=O)CCC1CC(=O)O</smiles>

1<smiles>CC1=C[C@@H](O)[C@H]2O[C@H]2[C@H]1O</smiles>

2<smiles>COc1cc(O)cc(C=CCCCC(=O)C[C@@H](C)O)c1C(=O)O</smiles>

3<smiles>[R]C(CCCCCc1cc(O)cc(OC)c1C(=O)OC(C)C)CC(C)C</smiles>

4a: $\mathrm{R}=\cdot\|\| \mathrm{OH} \quad$ 4b: $\mathrm{R}=\prec \mathrm{OH}$<smiles>COc1cc(O)cc(CCCCCC[C@H](O)[C@@H](C)O)c1C(=O)O</smiles><smiles>CO[C@@H](C)CC[C@H](O)CCCCc1cc(O)cc(O)c1C(=O)O</smiles><smiles>CO[C@@H](C)C[C@H](O)CCCCc1cc(O)cc(O)c1C(=O)O</smiles><smiles>CCOC(=O)c1c(O)cc(O)cc1CCCCCC(C)O</smiles>

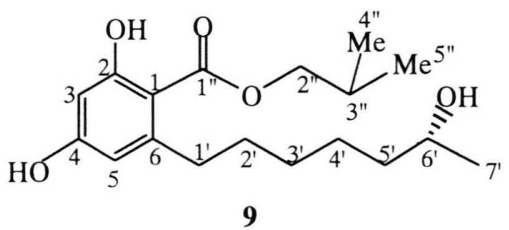

Fig. 1. Potato micro-tuber inducing compounds from Lasiodiplodia theobromae.

\section{Cultures and isolation}

The fungus was grown in $500 \mathrm{ml}$ flasks in a stationary phase at $25^{\circ} \mathrm{C}$ in the dark for 35 days, with each culture containing $200 \mathrm{ml}$ of $3 \%$ potatosucrose medium. The mycelium from 201 culture filtrate was immersed in acetone for 3 months. The acetone filtrate was concentrated to nearly 11 in vacuo and extracted with ethyl acetate. The extract was evaporated to dryness in vacuo and the residue $(11 \mathrm{~g})$ was chromatographed in a silica gel column, eluting successively with $\mathrm{CHCl}_{3}, \mathrm{MeOH}-$ $\mathrm{CHCl}_{3}(3: 97, \mathrm{v} / \mathrm{v}), \mathrm{MeOH}-\mathrm{CHCl}_{3}$ (20:80) and $\mathrm{MeOH}$. Micro-tuber forming activity was found in the $\mathrm{MeOH}-\mathrm{CHCl}_{3}$ (3:97) eluate. The residue from this eluate was rechromatographed successively with $\mathrm{MeOH}-\mathrm{CHCl}_{3}$ (3:97) and $n$-hexane-EtOAc (1:1) as eluent. Two active fractions A $(6.5 \mathrm{mg})$ and B (10.0 mg) were obtained.

\section{Isolation of $\mathbf{8}$}

Active fraction A was purified by HPLC on C18 column (Wakosil-II, $4.6 \times 250 \mathrm{~mm}$; flow rate $0.5 \mathrm{ml} /$ min; UV detector $210 \mathrm{~nm}$ ). Elution with a gradient mode of $70 \%$ methanol: $30 \%$ water containing $0.2 \%$ acetic acid to $100 \%$ methanol over $30 \mathrm{~min}$ yielded $2.1 \mathrm{mg}$ of $\mathbf{8}, \mathrm{R}_{\mathrm{t}}=24.58 \mathrm{~min}$.

$[\alpha]_{\mathrm{D}}^{25}-9.11^{\circ}$ (c $\left.0.9, \mathrm{MeOH}\right) ; \mathrm{EI}-\mathrm{MS} \mathrm{m} / \mathrm{z}$ (rel. int.): $296(\mathrm{M})^{+}(37), 279(5), 250$ (15), 232 (31), 214 (10), 196 (100), 183 (40), 168 (48), 150 (89), 149 (70), 124 (22), 123 (20), 69 (12); FD-MS m/z: 296 $(\mathrm{M})^{+}$(100); EI-HR-MS $\mathrm{m} / \mathrm{z} \quad\left(\mathrm{M}^{+}\right)$: Calcd. for $\mathrm{C}_{16} \mathrm{H}_{24} \mathrm{O}_{5}$ : 296.1624. Found: 296.1648; IR $v_{\max }$ (film) $\mathrm{cm}^{-1}: 3357,2931,1643,1548,1513,1444$, 1259; ${ }^{1} \mathrm{H}$ NMR and ${ }^{13} \mathrm{C}$ NMR see Tables I and II.

\section{Isolation of 9}

Active fraction B was first subjected to prep. TLC (silica gel $60 \mathrm{~F}_{254}$ ), developed with $n$-hexaneEtOAc-AcOH (4:3:0.01, v/v), and the main band (Rf. value $=0.38$ ) was further purified by prep. TLC employing $\mathrm{MeOH}-\mathrm{CHCl}_{3}$ (8:92, Rf. value = $0.40)$ as the eluting solvent to yield compound 9 (0.6 mg).

$[\alpha]_{\mathrm{D}}^{25}-15.5^{\circ}$ (c $0.6, \mathrm{CHCl}_{3}$ ); EI-MS $\mathrm{m} / \mathrm{z}$ (rel. int.): $324(\mathrm{M})^{+}(46), 279$ (8), 250 (18), 224 (53), 211 
(33), 168 (100), 150 (56), 111 (30), 97 (39), 71 (37), 57 (57), 55 (35); FD-MS $m / z: 324(\mathrm{M})^{+}$(100); FIHR-MS $m / z\left(\mathrm{M}^{+}\right)$: Calcd. for $\mathrm{C}_{18} \mathrm{H}_{28} \mathrm{O}_{5}: 324.1937$. Found: 324.1909; IR $v_{\max }(\mathrm{KBr}) \mathrm{cm}^{-1}: 3424,2988$, 1647, 1546, 1501, 1456, 1260; ${ }^{1} \mathrm{H}$ NMR and ${ }^{13} \mathrm{C}$ NMR see Tables I and II.

\section{Preparation of the MTPA esters of $\mathbf{8}$}

Mosher method (Ohtani et al., 1991) was applied to determine the absolute configuration of hydroxyl moiety in $\mathbf{8}$. The $(S)$-MTPA ester $(\mathbf{8 a})$ and $(R)$-MTPA ester (8b) (MTPA: 2-methoxy-2trifluoromethyl-2-phenylacetic acid) were prepared via the dimethyl derivative of $\mathbf{8}$. A solution of compound $8(0.7 \mathrm{mg}, 2.4 \mu \mathrm{mol})$, anhydrous potassium carbonate $(2.0 \mathrm{mg}, 14.4 \mu \mathrm{mol})$ and iodomethane $(3$ drops $)$ in dry acetone $(200 \mu \mathrm{l})$ was refluxed for $5 \mathrm{hr}$. The formation of dimethyl derivative was confirmed with ${ }^{1} \mathrm{H}$ NMR by observing two $-\mathrm{OCH}_{3}$ signals at $\delta 3.71$ and 3.73 . The reaction mixture was concd. in vacuo, and the residue was extracted with $n$-hexane for three times $(3 \mathrm{ml} \times 3)$. After removal of the solvent, the dimethyl derivative of $8(0.7 \mathrm{mg}, 2.1 \mu \mathrm{mol})$ was obtained. To a stirred soln. of the resultant dimethyl derivative $(0.35 \mathrm{mg}, 1.08 \mu \mathrm{mol})$ in dry methylene dichloride $(200 \mu \mathrm{l})$, DMAP $(0.26 \mathrm{mg}, 2.16 \mu \mathrm{mol})$, pyridine (1 drop) and MTPACl (2-methoxy-2trifluoromethyl-2-phenylacetyl chloride) (1 drop), (-)-MTPACl for $\mathbf{8 a}$ and (+)-MTPACl for $\mathbf{8 b}$ were added. After $10 \mathrm{hr}$, the reaction mixture was concd. in vacuo. The residue was subjected to prep. TLC on silica gel using $n$-hexane-EtOAc $(5: 1)$ to give the $(S)$-MTPA ester 8a and $(R)$ MTPA ester $\mathbf{8 b}$ respectively.

Compound 8a: FD-MS $m / z$ : $540(\mathrm{M})^{+},{ }^{1} \mathrm{H}$ NMR $\left(270 \mathrm{MHz} \mathrm{CDCl}_{3}\right): \delta 7.53(2 \mathrm{H}, \mathrm{m}), 7.41(3 \mathrm{H}, \mathrm{m})$, $6.31(2 \mathrm{H}, \mathrm{dd}, J=2.1,2.2 \mathrm{~Hz}, \mathrm{H}-3$ and $\mathrm{H}-5), 5.15$ $\left(1 \mathrm{H}, \mathrm{m}, \mathrm{H}-6^{\prime}\right), 4.35\left(2 \mathrm{H}, \mathrm{q}, J=7.2 \mathrm{~Hz}, \mathrm{H}-2^{\prime \prime}\right), 3.82$ $\left(3 \mathrm{H}, \mathrm{s}, \mathrm{OCH}_{3}\right), 3.80\left(3 \mathrm{H}, \mathrm{s}, \mathrm{OCH}_{3}\right), 3.56(3 \mathrm{H}, \mathrm{s}$, $\left.\mathrm{OCH}_{3}\right), 2.51\left(2 \mathrm{H}, \mathrm{t}, J=7.8 \mathrm{~Hz}, \mathrm{H}-1^{\prime}\right), 1.55(8 \mathrm{H}$, $\mathrm{m}, \mathrm{H}-2^{\prime}, \mathrm{H}-3^{\prime}, \mathrm{H}-4^{\prime}$ and $\left.\mathrm{H}-5^{\prime}\right), 1.35(3 \mathrm{H}, \mathrm{t}, J=7.0$ $\left.\mathrm{Hz}, \mathrm{H}-3^{\prime \prime}\right), 1.27$ (3H, d, $\left.J=7.1 \mathrm{~Hz}, \mathrm{H}^{-} 7^{\prime}\right)$.

Compound 8b: FD-MS $m / z: 540(\mathrm{M})^{+},{ }^{1} \mathrm{H}$ NMR $\left(270 \mathrm{MHz}, \mathrm{CDCl}_{3}\right): \delta 7.52(2 \mathrm{H}, \mathrm{m}), 7.40(3 \mathrm{H}, \mathrm{m})$, $6.31(2 \mathrm{H}, \mathrm{d}, J=2.3 \mathrm{~Hz}, \mathrm{H}-3$ and $\mathrm{H}-5), 5.13(1 \mathrm{H}, \mathrm{m}$, H-6'), $4.35\left(2 \mathrm{H}, \mathrm{q}, J=7.0 \mathrm{~Hz}, \mathrm{H}-2^{\prime \prime}\right), 3.81(3 \mathrm{H}, \mathrm{s}$, $\left.\mathrm{OCH}_{3}\right), 3.80\left(3 \mathrm{H}, \mathrm{s}, \mathrm{OCH}_{3}\right), 3.55\left(3 \mathrm{H}, \mathrm{s}, \mathrm{OCH}_{3}\right)$, $2.54\left(2 \mathrm{H}, \mathrm{t}, J=7.6 \mathrm{~Hz}, \mathrm{H}-1^{\prime}\right), 1.56\left(8 \mathrm{H}, \mathrm{m}, \mathrm{H}-2^{\prime}\right.$,
H-3', H-4' and $\left.\mathrm{H}-5^{\prime}\right), 1.35(3 \mathrm{H}, \mathrm{t}, J=7.0 \mathrm{~Hz}, \mathrm{H}-$ $\left.3^{\prime \prime}\right), 1.25\left(3 \mathrm{H}, \mathrm{d}, J=6.3 \mathrm{~Hz}, \mathrm{H}-7^{\prime}\right)$.

\section{Results and Discussion}

\section{Structures of $\mathbf{8}$ and $\mathbf{9}$}

Compound $\mathbf{8}$ was obtained as colorless oil and exhibited $[\alpha]_{D}^{25}-9.11^{\circ}$ (c $\left.0.9, \mathrm{MeOH}\right)$. The IR spectrum showed absorption bands for hydroxyl $\left(3357 \mathrm{~cm}^{-1}\right)$, a carbonyl of an aromatic ester linked by hydrogen-bonding $\left(1643 \mathrm{~cm}^{-1}\right)$ and an aromatic ring system $\left(1548 \mathrm{~cm}^{-1}\right.$ and $\left.1513 \mathrm{~cm}^{-1}\right)$. The molecular formula was determined as $\mathrm{C}_{16} \mathrm{H}_{24} \mathrm{O}_{5}$ by high resolution EI-mass spectra. A resorcinol derivative structure was deduced from its ${ }^{1} \mathrm{H}$ NMR and ${ }^{13} \mathrm{C}$ NMR spectra (Tables I and II). Thus, in the ${ }^{1} \mathrm{H}$ NMR there were signals due to a resorcinol ring $(2 \mathrm{H}, \delta 6.28,6.22, \mathrm{~d}, J=2.7$ $\mathrm{Hz}$ ), which was disubstituted with two side chains. One chain was supposed to be an ethyl ester group due to the presence of the signals at $\delta 4.28(2 \mathrm{H}$, $\mathrm{q}, J=7.0 \mathrm{~Hz})$ and $1.33(3 \mathrm{H}, \mathrm{t}, J=7.0 \mathrm{~Hz})$. There was also an aliphatic chain bearing a hydroxyl group at $\omega-1$, because a signal of a terminal methyl at $\delta 1.23 \mathrm{ppm}(\mathrm{d}, J=6.0 \mathrm{~Hz})$ was observed. Another terminal of the chain was a benzylic methylene $(\delta 2.83, \mathrm{t}, J=7.2 \mathrm{~Hz})$ which was linked to the aromatic system. The ${ }^{13} \mathrm{C}$ NMR had six signals of aromatic carbons, two of them being methine $(\delta$ $112.1,102.1)$ and the other quaternary $(\delta 166.6$, 163.6, 149.4 and 105.5). In addition to these signals, the ${ }^{13} \mathrm{C}$ NMR spectrum also showed those for

Table I. ${ }^{1} \mathrm{H}$ NMR data of compounds $\mathbf{8}^{\mathrm{a}, \mathrm{b}}$ and $\mathbf{9}^{\mathrm{a}, \mathrm{c}}$ (270 $\mathrm{MHz}, \mathrm{CD}_{3} \mathrm{COCD}_{3}$ for $\mathbf{8}, \mathrm{CD}_{3} \mathrm{OD}$ for $\mathbf{9}$ ).

\begin{tabular}{lll}
\hline Assignment & $\mathbf{8}$ & $\mathbf{9}$ \\
\hline $\mathrm{OH}$ & $11.56(\mathrm{~s})$ & $11.78(\mathrm{~s})$ \\
$2^{\prime \prime}$ & $4.28(\mathrm{q}, J=7.0 \mathrm{~Hz})$ & $4.13(\mathrm{~d}, J=6.6 \mathrm{~Hz})$ \\
$3^{\prime \prime}$ & $1.33(\mathrm{t}, J=7.0 \mathrm{~Hz})$ & $2.08(\mathrm{~m})$ \\
$4^{\prime \prime}, 5^{\prime \prime}$ & & $1.02(\mathrm{~d}, J=6.6 \mathrm{~Hz})$ \\
$3^{\prime}$ & $6.22(\mathrm{~d}, J=2.7 \mathrm{~Hz})$ & $6.23(\mathrm{~d}, J=2.5 \mathrm{~Hz})$ \\
5 & $6.28(\mathrm{~d}, J=2.7 \mathrm{~Hz})$ & $6.27(\mathrm{~d}, J=2.5 \mathrm{~Hz})$ \\
$1^{\prime}$ & $2.83(\mathrm{t}, J=7.2 \mathrm{~Hz})$ & $2.90(\mathrm{t}, J=7.9 \mathrm{~Hz})$ \\
$2^{\prime}$ & $1.52(\mathrm{~m})$ & $1.52(\mathrm{~m})$ \\
$3^{\prime}$ & $1.34(\mathrm{~m})$ & $1.28(\mathrm{~m})$ \\
$4^{\prime}$ & $1.34(\mathrm{~m})$ & $1.38(\mathrm{~m})$ \\
$5^{\prime}$ & $1.34(\mathrm{~m})$ & $1.38(\mathrm{~m})$ \\
$6^{\prime}$ & $3.58(\mathrm{~m})$ & $3.77(\mathrm{~m})$ \\
$7^{\prime}$ & $1.23(\mathrm{~d}, J=6.0 \mathrm{~Hz})$ & $1.19(\mathrm{~d}, J=6.2 \mathrm{~Hz})$ \\
\hline
\end{tabular}

a Assignments confirmed by two-dimensional experiments (COSY, HMQC and HMBC).

b $\mathrm{CD}_{3} \mathrm{COCD}$ signal at $\delta_{\mathrm{H}} 2.05$ as reference.

c $\mathrm{CD}_{3} \mathrm{OD}$ signal at $\delta_{\mathrm{H}} 4.78$ as reference. 
Table II. ${ }^{13} \mathrm{C}$ NMR data of compound $\mathbf{8}^{\mathrm{a}, \mathrm{b}}$ and $\mathbf{9}^{\mathrm{a}, \mathrm{c}}(270$ $\mathrm{MHz}, \mathrm{CD}_{3} \mathrm{COCD}_{3}$ for $\mathbf{8}, \mathrm{CD}_{3} \mathrm{OD}$ for $\left.\mathbf{9}\right)$.

\begin{tabular}{lrr}
\hline Assignment & $\mathbf{8}$ & $\mathbf{9}$ \\
\hline $1^{\prime \prime}$ & 172.6 & 171.7 \\
$2^{\prime \prime}$ & 62.2 & 71.9 \\
$3^{\prime \prime}$ & 14.7 & 27.1 \\
$4^{\prime \prime}, 5^{\prime \prime}$ & & 19.4 \\
1 & 105.5 & 105.5 \\
2 & 166.6 & 165.5 \\
3 & 102.1 & 101.5 \\
4 & 163.6 & 160.2 \\
5 & 112.1 & 110.6 \\
6 & 149.4 & 148.4 \\
$1^{\prime}$ & 37.6 & 36.4 \\
$2^{\prime}$ & 32.9 & 31.5 \\
$3^{\prime}$ & 30.9 & 29.5 \\
$4^{\prime}$ & 26.7 & 25.8 \\
$5^{\prime}$ & 40.5 & 39.2 \\
$6^{\prime}$ & 67.8 & 68.2 \\
$7^{\prime}$ & 24.3 & 23.6 \\
\hline
\end{tabular}

a Assignments confirmed by two-dimensional experiments (COSY, HMQC and HMBC).

b $\mathrm{CD}_{3} \mathrm{COCD}_{3}$ signal at $\delta_{\mathrm{C}} 206.5$ as reference.

c $\mathrm{CD}_{3} \mathrm{OD}$ signal at $\delta_{\mathrm{C}} 49.0$ as reference.

a benzylic methylene ( $\delta$ 37.6), five methylenes of the chain, secondary hydroxyl $(\delta 67.8)$ and the terminal methyl $(\delta 24.3)$. The signals due to an aromatic ester ( $\delta 172.6,62.2,14.7)$ were also observed. These values were in good agreement with those expected for a 2,4-dioxygenated benzoate bearing an alkyl substituent at C-6. The partial structure, $-\mathrm{CH}_{2}\left(\mathrm{CH}_{2}\right)_{4} \mathrm{CHOHCH}_{3}$, was well resolved by $\mathrm{HMBC}$ and ${ }^{1} \mathrm{H}-{ }^{1} \mathrm{H}$ COSY spectra (Fig. 2). Starting from the $\mathrm{H}-1^{\prime}$ signal at $\delta 2.83$, every proton on the seven carbons of the chain was assigned unambiguously and the chemical structure was determined to be ethyl-2, 4-dihy- droxy-6-(6'-hydroxyheptyl)benzoate. Assignments of protons to the carbons were made in conjunction with HMQC and HMBC.

The absolute configuration at C-6 $6^{\prime}$ of $\mathbf{8}$ was determined by an advanced Mosher method, based on the analysis of the difference of the ${ }^{1} \mathrm{H}$ NMR chemical shifts between the $(S)$ - and $(R)-$ MTPA esters of $\mathbf{8}$. In this process, 8 was first methylated with iodomethane, and then converted to MTPA esters: (8a) $[(S)-$ MTPA $]$ and $(\mathbf{8 b})[(R)$ MTPA]. The assignments of $\mathbf{8 a}$ and $\mathbf{8 b}$ were achieved by ${ }^{1} \mathrm{H}$ NMR and ${ }^{1} \mathrm{H}-{ }^{1} \mathrm{H}$ COSY spectral analyses, and the proton chemical shift differences between $\mathbf{8 a}$ and $\mathbf{8 b}$ were investigated (Fig. 3). The tendency of positive value $(+0.02)$ was observed in methyl protons at C-7' and methine proton at C$6^{\prime}$, and negative values $(-0.03)$ in benzylic methylene $\left(\mathrm{C}-1^{\prime}\right)$ and $(-0.01)$ in other methylenes $(\mathrm{C}$ $\left.2^{\prime} \sim \mathrm{C}-5^{\prime}\right)$, indicating an $R$ configuration at C- $6^{\prime}$. Thus, the structure of $\mathbf{8}$ was deduced as ethyl $\left(6^{\prime} R\right)$-2,4-dihydroxy-6-(6'-hydroxyheptyl)benzoate.

Compound 9 was obtained as colorless oil, and exhibited $[\alpha]_{D}^{25}-15.5^{\circ}\left(\mathrm{c} 0.6, \mathrm{CHCl}_{3}\right)$. The infrared spectrum indicated the presence of a hydroxyl group $\left(3424 \mathrm{~cm}^{-1}\right)$, an aromatic ester $\left(1647 \mathrm{~cm}^{-1}\right.$ and $\left.1260 \mathrm{~cm}^{-1}\right)$ and an aromatic ring system (1548 $\mathrm{cm}^{-1}$ and $\left.1513 \mathrm{~cm}^{-1}\right)$. The FD- and EI-mass spectra of 9 gave the molecular formula of $\mathrm{C}_{18} \mathrm{H}_{28} \mathrm{O}_{5}(\mathrm{M})^{+}$. The ${ }^{1} \mathrm{H}$ - and ${ }^{13} \mathrm{C}$ NMR spectral data of 9 bore good resemblance to that of $\mathbf{8}$. Comparison of the spectral data with those of $\mathbf{8}$ indicated the same resorcinol derivative skeleton with an alkyl substituent at C-6. This alkyl substituent has been found to be a seven-carbon chain with the same substitution pattern, a hydroxyl group at $\mathrm{C}-6$ '. The ${ }^{1} \mathrm{H}$ NMR showed the signals

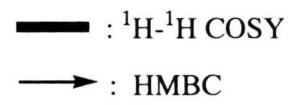

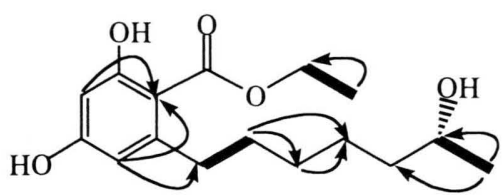

8

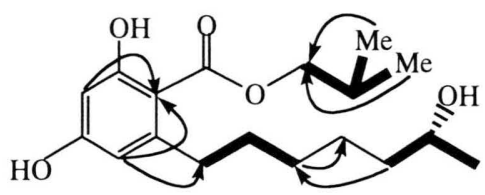

9

Fig. $2 .{ }^{1} \mathrm{H}-{ }^{1} \mathrm{H}$ COSY and HMBC correlations observed in 8 and 9. 
<smiles>CCOC(=O)c1c(CCCCCC[C@H](C)OC(=O)C(OC)(OC)c2ccccc2)cc(OC)cc1OC</smiles>

Structure of MTPA ester

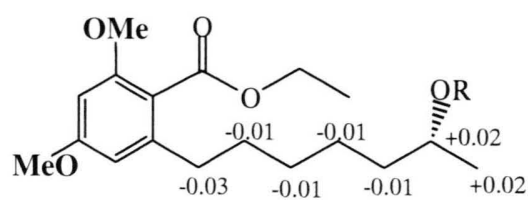

8a $\mathrm{R}=(S)-\mathrm{MTPA} ; \mathbf{8 b} \mathrm{R}=(R)-\mathrm{MTPA}$

Fig. 3. MTPA derivatives of $\mathbf{8}$ and the ${ }^{1} \mathrm{H}$-NMR chemical shift differences [( $\left.S\right)$-MTPA- $(R)$-MTPA].

due to a resorcinol ring $(2 \mathrm{H}, \delta 6.27,6.23, \mathrm{~d}, J=2.5$ $\mathrm{Hz})$, a terminal methyl $(\delta 1.19, \mathrm{~d}, J=6.2 \mathrm{~Hz})$ in the chain, and a benzylic methylene $(\delta 2.90, \mathrm{t}, J=$ $7.9 \mathrm{~Hz})$. Instead of the signals for an ethyl ester observed in $\mathbf{8}$, a doublet peak at $\delta 1.02(6 \mathrm{H}, J=$ $\left.6.6 \mathrm{~Hz}, \mathrm{CH}_{2} \mathrm{CH}\left(\mathbf{C H}_{3}\right)_{2}\right)$ correlated with a multiple peak at $\delta 2.08\left(1 \mathrm{H}, \mathrm{CH}_{2} \mathbf{C H}\left(\mathrm{CH}_{3}\right)_{2}\right)$ and a doublet peak at $\delta 4.13\left(2 \mathrm{H}, J=6.6 \mathrm{~Hz}, \mathbf{C H}_{2} \mathrm{CH}\left(\mathrm{CH}_{3}\right)_{2}\right)$ which indicated the presence of an isobutyl group in 9. Thus, the chemical structure of 9 was proposed as isobutyl-2,4-dihydroxy-6-(6'-hydroxyheptyl)benzoate. This conclusion can be confirmed further by the ${ }^{13} \mathrm{C}$ NMR data. The complete NMR assignments of 9 are given in Tables I and II according to the HMQC, HMBC and ${ }^{1} \mathrm{H}_{-}{ }^{1} \mathrm{H}$ COSY spectra (Fig. 2). Because of the small amount of $\mathbf{9}$, it was difficult to determine the absolute configuration of C- $6^{\prime}$ by advanced Mosher method. Comparison of its optical rotation $\left([\alpha]_{\mathrm{D}}^{25}-15.5^{\circ}\right)$ with that of $8\left([\alpha]_{\mathrm{D}}^{25}-9.11^{\circ}\right)$, suggested that $\mathrm{C}-6^{\prime}$ has the same $R$ configuration as $\mathbf{8}$. Hence, the structure of 9 is proposed as isobutyl (6'R)-2,4-dihydroxy-6-(6'-hydroxyheptyl)benzoate.

Retrosynthetic analysis of $\mathbf{8}$ and $\mathbf{9}$ would easily give the same acid, together with ethyl and isobutyl alcohols, respectively. It is conceivable that a free acid exists as the common precursor for $\mathbf{8}$ and 9. Furthermore, it is fair to suggest that esterification of this acid with different alcohols would simply give a myriad of compounds in nature-still undiscovered. Benzoic acid derivatives are known that have side chains which may be closed to form a lactone ring. Lasiodiplodin and de- $O$-methyl lasiodiplodin (Aldridge et al., 1971) together with their hydroxyl derivatives $(\mathbf{4 a}, \mathbf{4 b}, \mathbf{5}, \mathbf{6}$ and $\mathbf{7})$ and 5-oxolasiodiplodin $\mathbf{3}$ are 12 -member lactone ring which have been isolated from the same fungus. Compound 8 and $\mathbf{9}$ that bear a seven-carbon side chain with hydroxyl group are capable of forming a lactone ring. But these are two carbons short compared to lasiodiplodin and de- $O$-methyl lasiodiplodin and their derivatives. The presence of $\mathbf{8}$ and $\mathbf{9}$ give an interesting hint to the biosynthesis of lasiodiplodin and its congeners.

\section{Biological properties}

Using bioassay of single-node stem segment cultures, compound $\mathbf{8}$ was found to have micro-tuber inducing activity (Fig. 4) at the same concentration $\left(10^{-4} \mathrm{M}\right)$ as that of theobroxide, which was also obtained from the same fungus. The activity of $\mathbf{8}$ was lower than that of jasmonic acid, which is usually applied at $10^{-5} \mathrm{M}$ as a positive control. The negative control (using medium without any added compounds) showed no activity at all. Although not subjected to bioassay because of its small amount, compound 9 might possess similar

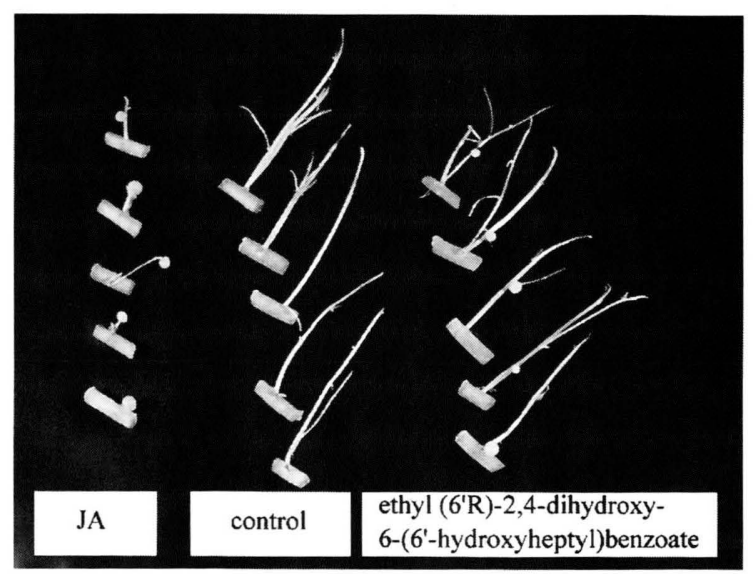

Fig. 4. Potato micro-tubers induced by 8 at $10^{-4} \mathrm{M}$ (right), compared to jasmonic acid at $10^{-5} \mathrm{M}$ (left) and negative control (middle). 
activity since it closely resembled $\mathbf{8}$ in structure and was isolated from an active fraction. Up to now, there is no report about the effect of resorcinol lipids on potato micro-tuber induction. The role of resorcinol lipid $\mathbf{8}$ in micro-tuber induction is interesting but unknown at the moment.

Based on their structures, compound $\mathbf{8}$ and $\mathbf{9}$ can be classified as resorcinol lipids. This class of compound occurs widely in plant and microorganism and are known to have various biological functions such as antimicrobial, antiparasitic, regulation of

Aldridge D. C., Galt S., Giles D. and Turner W. B. (1971), Metabolites of Lasiodiplodia theobromae. J. Chem. Soc. (C). 1623-1627.

Drengler Keith A. (1991), Resorcycle acid lactone derivatives as animal growth promotants. United States Patent, 5, 041, 610.

Koda Y. and Okazawa Y. (1988), Detection of potato tuber-inducing activity in potato leaves and old tubers. Plant Cell Physiol. 29 (6), 969-974.

Kozubek A. (1999), Resorcinolic lipids, the natural nonisoprenoid phenolic amphiphiles and their biological activity. Amer. Chem. Soc. 99 (1), 1-25.

Matsuura H., Nakamori K., Omer E. A., Hatakeyama C., Yoshihara T. and Ichihara A. (1998), Three lasiodiplodins from Lasiodiplodia theobromae IFO 31059. Phytochemistry 49 (2), 579-584. plants (Kozubek, 1999) and promotion of growth in food-producing animals (Drengler et al., 1991). Compound 8 and 9 being new members of the resorcinol lipid family might also have potentialities on such aspects.

\section{Acknowledgements}

The authors thank Dr E. Fukushi and Mr. K. Watanabe for FD-MS, EI-MS, EI-HR-MS, HMBC and HMQC measurements.

Nakamori K., Matsuura H., Yoshihara T., Ichihara A. and Koda Y. (1994), Potato micro-tuber inducing substances from Lasiodiplodia theobromae. Phytochemistry 35 (4), 835-839.

Ohtani I., Kusumi T., Kashman Y. and Kakisawa $\mathrm{H}$. (1991), High-field FT NMR application of Mosher's method. The absolute configurations of marine terpenoids. J. Am. Chem. Soc. 113, $4092-4096$.

Yang Q., Asai M., Matsuura H. and Yoshihara T. (2000), Three potato micro-tuber inducing hydroxylasiodiplodins from Lasiodiplodia theobromae. Phytochemistry, in press. 